\title{
Familial Alzheimer's Disease, Type 3
}

National Cancer Institute

\section{Source}

National Cancer Institute. Familial Alzheimer's Disease, Type 3. NCI Thesaurus. Code C123412.

Alzheimer's disease with an early onset (starts before the age of 65). It is caused by mutations in the PSEN1 gene. 